\title{
Let's Hang Ourselves Immediately! On Death and Suicide
}

JS: I am never not thinking about suicide and death. Two remarks, a pair of dice, tumble across my consciousness. One: "The thought of death wonderfully concentrates the mind" (Dr. Johnson) and Two: "The thought of death gets one through many long nights" (Nietzsche). I long ago understood that Absurdity (à la Camus) not Morbidity was my life-blood and somehow that writing was the only way I could deal with the incandescent consciousness of the certainty of death. Death became for me a life-sentence, a huge collection of life-sentences. I suppose that is why Hamlet has emerged as the cause and effect of my death-haunted life. Hamlet in the graveyard, cupping Yorick's skull, staring into the abyss and making infinitely sad jests about our mortal condition, has been the alpha and omega of my imagination. That the sound and fury of life end up "signifying nothing" seems to me at once "The horror! The horror!" and part of the "final soliloquy of the interior paramour." To keep signifying nothing. That also sounds like a Beckettian raison d'être. To keep staining the silence. Not to stain is not to be. About nothing there must be much ado. And is not a dialogue also part of the will to stain the silence? We exchange (night) thoughts to give ourselves the impression we exist.

RB: Your dice-one thinks of Mallarmé-rattle like eloquent bones, but the topic of death and suicide leaves me as cold as camphor. Certainly there are cases where it makes sense to kill oneself, and I will happily defend the right of anyone to shuffle off this mortal coil. But I find it difficult to take seriously the romance of suicide. Hamlet's Melancholia, Werther's Weltschmerz and Camus's

How to cite this book chapter:

Begam, R. and Soderholm, J. 20I 5. Let's Hang Ourselves Immediately! On Death and Suicide. In: Begam, R. and Soderholm, J. Platonic Occasions: Dialogues on Literature, Art and Culture. Pp. 8I-94. Stockholm: Stockholm University Press. DOI: http://dx.doi.org/IO.I6993/sup.baa.e. License: CC-BY-NC-ND. 
Absurdity strike me as blinds, convenient vehicles for transforming the errors and insufficiencies of youth into existential crises. Once we push through the metaphysical posturing, what we discover in all three cases is personal failure of one kind or another. Hamlet failed to be a good Prince, Werther failed to be an adequate lover and Camus failed to fight the Nazis—at least, with any success. Rather than confront their own deficiencies, they constructed philosophies in which their impotence is the fault not of themselves but of the universe.

Byron, on the other hand, takes a more jaundiced view of young men who seek refuge in metaphysics:

'Twas strange that one so young should thus concern

His brain about the action of the sky;

If you think 'twas philosophy that this did,

I can't help thinking puberty assisted.

(Don Juan I, 93)

JS: I don't think there's anything particularly pubescent about Hamlet's meditations about death. Both Seneca and Montaigne trickle through his mortal reflections and pedigree his deathhaunted consciousness. The Byronic squib you cite is clever enough but lofts us into matters metaphysical. Like you, I am not concerned with the romance of suicide (a strictly literary affair), but with the question of authenticity, Heidegger's Being-towards-death. Hamlet anticipates that authenticity in his tragic-comic remarks in the graveyard scene. Unlike Shakespeare, Heidegger never seems to find any humor whatsoever in our mortal condition. Hamlet's darkest pun-that Yorick is "quite chopfallen"—suggests that one can be both exquisitely sad and hilarious at the same time. That alloy is hard-won and, it seems to me, hardly juvenile. Hamlet is leagues beyond the simpering sorrows of young Werther.

RB: When I speak of the "romance of suicide," I am responding to the celebrated opening to The Myth of Sisyphus: "There is but one truly serious philosophical problem and that is suicide." A godless universe is an "absurd" universe, Camus claims, where meaning, value and truth have ceased to exist and where man labors endlessly at a futile task and then dies. Camus believes that 
human mortality is a problem, because-despite his atheismhe still accepts Christianity's central assumption: that Being and Time are antithetical. The classic statement of this position comes from Plato, but it enjoys an afterlife in both Neoplatonism and Christianity. Simply stated, this position holds that it is only through the Soul that we can experience true Being, because true Being is Timeless and the Soul alone enables us to lift ourselves out of Time.

All of this changes in 1927, when Heidegger publishes his magnum opus and turns Platonic ontology on its head. His argument is that Sein und Zeit-Being and Time-are not only inseparable (note the pun in the German) but in some important sense indistinguishable. Indeed, it is only through Zeitlichkeit ("temporality") that man experiences Being, or as Heidegger would say that Sein is disclosed to Dasein. On this reading, mortality is not the problem of the human condition but its solution-what confers significance, however contingent, on our three-score ten. As Heidegger (and Nietzsche) observe, an eternal life-one that requires no choices-would be a mere procession of events, a tedium of parataxis.

So my argument is that Camus, Werther and, yes, even Hamlet, romance suicide out of a Christianity that they themselves don't entirely understand. The "absurdity" of mortality is a fiction invented by the Church. A good pagan like Lucretius grasped this fact.

JS: Then how do you characterize the absurdity of Estragon and Vladimir wanting to hang themselves immediately because they might enjoy a posthumous erection? It's not a Christian joke. It's not an existential joke. But it's one of the funniest and saddest lines in the play.

RB: Indeed. The exchange is funnily unhappy and unhappily funny:

ESTRAGON: What about hanging ourselves?

VLADIMIR: Hmm. It'd give us an erection.

ESTRAGON: (highly excited). An erection! 
VLADIMIR: With all that follows. Where it falls mandrakes grow. That's why they shriek when you pull them up. Did you know that?

ESTRAGON: Let's hang ourselves immediately!

As I read it, "Let's hang ourselves immediately" fully acknowledges Estragon and Vladimir's temporality-the fact that they exist in and through time-with a play on the Elizabethan pun: to die is not to go, but to come. Death is rhymed with Love, with its low points and high points, its anticipations and gratifications, its rising action, complications and final denouement. Post coitum omne animal triste est. Et post vitam? Who knows and who cares? Life is a performance and the final curtain a framing device. That the play ends betokens neither futility nor absurdity. Just narrative good sense.

JS: The entire play is Gogo and Didi hanging around. But to see the final curtain coming-to know with certainty it's coming: is not that where (or when) the sound and fury start to signify nothing in a way that, finally, is not edifying? As when Ivan Ilych, hanging curtains on some silly ladder, has his little fall and bruises himself unto death? It's not the fall into mythos and narrative plenitude that addles my night-thoughts. It's that sense of an ending when no artistic friskiness in the artificed world can keep the last syllable of recorded time from becoming the excruciating symphony of Ivan's three-day, mortal shriek.

RB: Rimbaud writes, "Comme je deviens vieille fille, à manquer du courage d'aimer la mort!" ["What an old lady I'm becoming, to lack the courage to love death!"]. Yes, most of us funk it in the end, and it's easier to talk about death as Lucretius might than to confront it squarely when it breathes its cold breath down our necks. But as much as death terrifies Ivan Ilyich, Tolstoy makes clear that his hero's struggle with mortality has improved him immeasurably. Ivan's fall is at once symbolic and fortunate. He is transformed from a petit bourgeois, preoccupied with card games and social gossip, into a fully sentient human being who actually comes to understand something of the life 
he must leave. Not only is the mind concentrated by death. It is formed by it.

Of course, Waiting for Godot is a play about two characters who attempt to turn chronos into kairos. They show us how suspended time can become redeemed time, not through the intervention of God the Father but by the pratfalls and hat tricks we invent while waiting for Him. So it is that ousia is produced out of an infinitely deferred parousia.

JS: I don't think Gogo and Didi “attempt" to do much of anything that resembles the heroic imperative of kairos. Rather than string the bow in the great hall, they puke away their puke of a life (Kronos devouring his kids and vomiting them) by stringing each other along, slack lyres, trying ever more desperately to strum their way through the next moment. Only Beckett could make this shameless and empty bantering, this yes yes no no yes yes, into a play of voices with ludic and lyric suggestiveness. In actual life-God[ot] help us-being trapped in chronos is rather less amusing. That life is a performance does little to sustain me. That art is a performance does something small to sustain me. My struggle with mortality may have improved me once. Now it makes me pratfall into sickly emotion.

RB: I am thinking not of "heroic" but of "significant" time. In The Sense of an Ending, Frank Kermode defines chronos as "passing" or "waiting time" and kairos as "a point in time filled with significance, charged with meaning derived from its relation to the end." In the Greek tradition, kairos is the "moment that must be grasped," and it is for that reason that the sculptor Lysippos represents him with a forelock that can symbolically be seized, as one seizes the day. Beckett plays with this tradition in Murphy when the narrator writes, "Let us now take Time ... bald though he be behind, by such few sad short hairs as he has." And in Waiting for Godot, when Vladimir urges that he and Estragon help a fallen Pozzo, it is precisely out of a desire to convert chronos into kairos: "Let us not waste our time in idle discourse! Let us do something, while we have the chance! It is not every day that we are needed. Not indeed that we personally are needed." 
Beckett's play is an experiment in how humans transform "suspended" time into "redeemed" time. And that transformation occurs because "meaning" derives from our "sense of an ending." In the closing moments of Waiting for Godot, Vladimir soliloquizes in language reminiscent of Shakespeare: "Astride of a grave and a difficult birth. Down in the hole, lingeringly the grave-digger puts on the forceps." I like to imagine that Beckett is here thinking of the graveyard scene in Hamlet. Yorick is reborn out of Ophelia's grave, his skull tossed up by the grave-digger down in the hole. And just as Yorick has borne Hamlet on his shoulders, so Hamlet now bears Yorick in his hands. Death and birth go, as it were, hand-in-hand. They are the Zeitlichkeit that gives the "design" to Dasein.

You are fond of Hamlet's description of Yorick as "quite chopfallen," a dark pun that, as you say, combines the exquisitely sad and the hilariously funny. I'm partial to another moment of theatrical magic-when Hamlet calls Yorick "a fellow of infinite jest." As the audience witnesses Hamlet holding the skull, it becomes keenly aware of just how "finite" that jest was. Would those "flashes of merriment" have "set the table on a roar" had Yorick lived forever? Do the immortals laugh and cry at all? Or is theirs a life without care, pain or pleasure that simply never ends?

JS: Why does the Sibyl want to die? Who could blame her? I also forgot to ask for eternal youth. And look what happened. Just more narrative-in a bad sense.

RB: Sibyl wants to die because she's shrivelled up to the size of a small rodent. Death is not absurd. Old age is.

JS: Hence, the happy resolution to the Achillean dilemma. Better the short, heroic, kairos-rich life than slowly wasting away under the auspices of chronos. Or, in a modern register, the famous last words of Gabriel in Joyce's "The Dead": "Better pass boldly into that other world, in the full glory of some passion, than fade and wither dismally with age." The problem is that most of us become so accustomed to being more or less pampered pigs that we forget that an heroic initiative still exists. We 
forget, to quote Tennyson's "Ulysses," that "it's not too late to seek a newer world." Call it the Ithaca Complex. But if one is to remain alive in this absurd world, one should at least have the good (narrative?) sense to make our true Penelope Flaubert. Then we might read the latter's well-known remark to Louise Colet ("What I would like to write is a book about nothing") with a renewed sense of adventure. He later writes to Elisa Schlesinger: "And so I will take back up my poor life, so plain and so tranquil, where phrases are adventures and the only flowers I gather are metaphors."

I conclude: the only "full glory" available to us is in not merely the stewardship of art, but its production. Otherwise, the plain, tranquil life leaves no wake. Flaubert withered dismally. Madame Bovary still flowers. No wonder so many artists have been beguiled by the idea of immortalizing themselves by writing. But Keats understood the vanity of that human wish when he insisted that his epitaph read: "Here lies one whose name was writ on water." Good lad. Well-wrought by his Being-towards-death.

RB: An interviewer once asked Woody Allen, "Do you hope to achieve immortality through your art?" To which Allen replied, "No, I hope to achieve immortality by not dying." Unlike Allen, I don't want to live forever, but I understand and appreciate his indifference to “posterity." Shakespeare's thirty-seven plays and I 54 sonnets mean as much to the man who penned them as the chop-fallen skull means to Yorick. I like to imagine that Shakespeare derived pleasure-intense pleasure-from writing the words "Shall I compare thee to a summer's day" or "The quality of mercy is not strained" or "Nothing will come of nothing, speak again." But from where he lies moldering in his grave, the Collected Works are as important to him as the Telephone Directory of Lower Slovenia is to me. Loam to stop a beer-barrel, clay to keep the wind away. The argument for crafting any kind of life-whether Achillean or Flaubertian-is the happiness one experiences while living it. The rest is silence.

So I ask, why do you care if your life "leaves a wake"? Or if you "immortalize" yourself through art? I want to write my name not in water but in wine. What matters are not the lees that remain 
after the glass has been emptied, but the fruit that was drunk while the glass was full.

JS: We have nothing to disagree about on this point. The only reason not to hang ourselves immediately is so we can read and write lines as hilariously mordant as "Let's hang ourselves immediately!" I don't know about happiness, but Beckett's wit certainly gives me plenty of disinterested satisfaction. That's just enoughso far-to keep me from the actual rope.

RB: I'm glad to hear you no longer regard literary production as a promissory note to be cashed in the Hereafter. Perhaps I can now also persuade you to abandon the notion that "Absurdity à la Camus is your life blood"?

To me, Camus's philosophy represents a failure of nerve. He no longer believes in the myth of God the Father, but he can't quite bring himself to do without the metaphysical comfort that myth provides. He is, in other words, a reluctant atheist. The death of God has the effect of collapsing Being into Time, thereby killing off Man's eternal soul, a situation Camus regards as "absurd." He allegorizes that absurdity by treating mortality as a Sisyphean burden and then by transforming Sisyphus into an existential hero, a Promethean figure of revolt. But what Camus seems to have forgotten is there are no gods to revolt against. This leads me to three related questions. Why is mortality absurd? Indeed, why is mortality a problem? More to the point, why is it even a matter of concern?

JS: I have no great intellectual love for Camus. When he concludes "One must imagine Sisyphus happy," I am left wondering about his "reasoning." I don't think Sisyphus is at all happy despite his immersion in the existential glory of his task.

My preoccupation with death is not an Absurd labor of love. Death is a matter of concern to me because the prospect of eternal nothingness-while a positive relief in one sense-is not pleasant to consider. What unhinges me more than anything is that there are no sound or suggestive metaphors for death. I came up with one I like because it demolishes a cliché I loathe. So sometimes 
I think of death as "the tunnel at the end of the light." My tunnel vision has no philosophical pedigree. Perhaps I was cheering myself up at the beginning of this dialogue in imagining that it does. The fact of death stupefies me. That we can go from quintessence to dust in a single moment is to me the most horrifying thing imaginable. If this still sounds adolescent, then I must admit that I am arrested in adolescence. I am not "sorted" when it comes to the big D, and I suspect I never will be. And reading Heidegger or Tolstoy or Shakespeare won't get me there. So I am depressed. I have been since I was ten years old.

RB: Disease, infirmity, old age-these are the things that unsettle me. Or so I imagine. I suppose it's easy to be philosophical about death, when one is still hail and hardy. You earlier mentioned Achilles choosing kairos over chronos. No doubt you remember Odysseus' encounter with the shade of Achilles in Book XI of The Odyssey. The "Man of Many Turns," the great strategist and talker, attempts to console his departed friend:

Was there ever a man more blest by fortune

Than you, Achilles? Can there ever be?

We ranked you with the immortals in your life,

We Argives did, and here your power is royal

Among the dead men's shades. Think, then, Achilles:

You need not be so pained by death.

To which Achilles bitterly responds:

Let me hear no smooth talk

Of death from you, Odysseus, light of councils.

Better, I say, to break sod as a farm hand

For some poor country man, on iron rations,

Than lord it over all the exhausted dead.

It is one of the most extraordinary moments in literature. Better the meanest slave than the noblest hero, as long as one still stands in the light of day. Perhaps it's true that in the end, despite all the "smooth talk," chronos casts out kairos. Perhaps, when finally confronted with death, we will do anything-betray our friends, betray even ourselves-for just one more breath of life. Is it that 
sentiment that fills the intensive-care units and the assisted-living facilities? Which is worse? The horror of death? Or the horror of a life not worthy of being lived?

JS: I don't know which is worse: nothingness or a life lived poorly. My fear is the blend: a life lived poorly that ends in nothingness. Perhaps that is one reason I drink. Byron wrote: "Man, being mortal, must get drunk." I know that Baudelaire's winsome "Be drunken continually" is a flowering of that necessary evil, but I prefer Byron's more honest and frankly abject response to our mortal condition. Chronos is the death of all kairos. I don't see any way of thinking outside that coffin.

RB: Perhaps you know Karel Čapek's play, The Makropulos Case, adapted as an opera by Leoš Janáček? It tells the story of certain E.M., a.k.a. Elina Makropulos, Emilia Marty and Ellian MacGregor, who has achieved immortality thanks to a special elixir. When we encounter her she is 342 years-old, but in health and appearance she is a beautiful and vibrant forty year-old. Men vie for her favor and many a heart is broken.

The English philosopher, Bernard Williams, wrote an essay about The Makropulos Case, in which he reflected upon the problem of death. For Williams, the play and opera illustrate that "immortality, or a state without death, would be meaningless." He goes on to point out that at the time of the action, E.M.'s "unending life has come to a state of boredom, indifference and coldness. Everything is joyless: 'in the end it is the same,' she says, 'singing and silence.'" She finally refuses to take the elixir againthe plot assumes a dose must be swallowed every 300 years or so-and she dies. Immortality, Čapek, Janáček and Williams argue, would be insupportably tedious.

So I ask: If you could drink E.M.'s elixir of immorality, would you? And if yes, how would you spend eternity?

JS: There's a short story out there (I think by Singer) that ends with a male ghost saying to his female lover-ghost, after having floated about for a while, "Immortality was my greatest disappointment." Is that the converse or obverse of "Let's hang 
ourselves immediately!"? I understand that death necessarily shapes our every living moment (or should), but my problem is that the shaping is really a crushing, a demolition. It is sometimes so crushing that I want to hang myself immediately. That I have not suggests at once my tenacity and cowardice. Who can adjudicate between these? Not I. Not clearly. I sometimes think that you simply enjoy life more than I do. And that enjoymentbecause you are so reflexively high-brow-nourishes itself with the headiest of elixirs. If you were a poet, you would be crafting an irregular Pindaric Ode called: "Intimations of Mortality taken from fairly recent Lucubrations in Adulthood.”

RB: Although I greatly admire Wordsworth, his sensibilityespecially in the "Intimations" ode-stands at a great distance from my own. Like you, he was death-haunted, even deathobsessed. From "We Are Seven" and the Lucy Poems to "Michael," "Intimations of Immortality" and, of course, "Elegiac Stanzas," he may be England's greatest poet of mortality. Oddly, he experienced his own birth as a kind of death and spent his life seeking consolation in memory, time and nature-until the latter killed off his brother and he became inconsolable.

You have lived so much of your life in the belief that Hamlet and Don Juan were your alter-egos. But perhaps the Man Behind the Curtain was really the Bard of Grasmere? Does Wordsworth add anything to our conversation about death? And how close is his graveyard-sensibility to your own?

JS: Not too long ago, I found myself wandering near Windermere along paths that took me to half-finished sheepfolds that had not altered in two-hundred years and more, the straggling ruins that Wordsworth found so worthy of words. What the sad shepherd did not finish building, Wordsworth does, poetic stone by stone, and yet his poems are haunted by loss, even preemptive loss, and not even the most well-wrought poem will earn Wordsworth the right to enjoy the "animal tranquility" he celebrates in "Old Man Traveling." So I think you are right to notice certain similarities. Although I would rather have Byron's amor fati coursing (or Corsairing) through my veins, the truth 
is that I share Wordsworth's fond dread that "Lucy should be dead." The honeymoon of childhood memories does nothing but make me realize how I shall never again lightly draw my breath. When I try to breathe it feels like the opening measures of Mozart's Requiem - a labored, painful breathing. From time to time I can enjoy the brio and effervescence of the Overture to Don Giovanni, but more often than not I am brought back into the ruined sheepfold of my mortal condition. Few can stare into the Abyss and come away giggling, as Byron and Beckett do-the lucky bastards.

RB: And yet death is precisely the enabling condition of Wordsworth's poetry. The Light-which he sometimes calls Lucy, sometimes Luke-must be lost so that Wordsworth can lift up the stone that Michael will not, thereby transmuting the mute matter of everyday life into the still sad music of humanity. Like the Simple Child of "We Are Seven," the artistic imagination plaits its garlands in the shadow of the graveyard. And isn't that what art has always done? Shklovsky's "defamiliarization" (ostranenie) and Brecht's "alienation-effect" (Verfremdungseffekt) are about breaking down routine perception, breaking up habits of mind that bleed the color and shape out of life, turning it into a "chronic" condition. In Critique of Judgment, Kant argues that the aesthetic is born out of the "free play of imagination and understanding." When we look at Monet's painting of a haystack and then think about what it represents-the farmer's haystack-we are momentarily disoriented as we attempt to align perception and cognition, to correlate what the mind sees with what it knows. Monet has painted something that both is and is not a haystack, and as we mentally process the difference-surrendering ourselves to "the free play" of aesthetic sensibility-habitual time, space and perception fall away. In other words, art transforms chronos into kairos, and it does so precisely by insisting on our temporality. As Walter Pater put it: "art comes to you proposing frankly to give nothing but the highest quality to your moments as they pass, and simply for those moments' sake."

You said earlier that mortality so thoroughly shapes your every moment that you sometimes feel crushed by it. Is it the fact of 
mortality that weighs upon you? Or the anxiety that your life has become more chronos than kairos?

JS: Yes-if Homer, underworldly Achilles, Lucy, Luke, Wordsworth and Pater taught us anything it is that kairos is our Shepherd. We shall not want. Art [hay]stacks up for us precisely because it seizes its moment. To the extent that I can live inside works of art (I once fell asleep in the painting of Van Gogh's bed), I can tolerate our glass of mortality. But when human voices wake me, I drown in chronos. My diseased heart is the graveyard I carry around inside me, but it does little to transmute the mute matter you refer to. And if one cannot be the constant alchemist, then what's the point of going on? The untransmuted life is not worth living. So the good news is the bad news: when I look in the mirror I see Yorick's skull emerging. It usually makes me pour myself another drink. And then look for a painting or a symphony or a metaphor to fall into.

RB: I think we've agreed, contra Camus, that mortality does not make life fundamentally absurd. But neither does it make life fundamentally worthwhile.

You mentioned Nietzsche. I like to imagine that the title of The Joyful Wisdom (Die Fröliche Wissenschaft) is meant to play off the "Glad Tidings" of the Gospels. The realization that the Good, the True and the Beautiful are not given by God or Nature-that values are constructed by humans and are therefore contingent-is for Nietzsche good news, a liberating and exhilarating form of knowledge. Sartre says much the same in his back-of-the-cereal box formulation, "existence precedes essence." Humans are radically free but with that freedom comes the responsibility of choice. And we cannot choose not to choose. There are many different ways of making our lives signify. But if we fail-Nietzsche and Sartre are stern libertarians-then we have only ourselves to blame.

For most of us our lives are works in progress, with high points, low points and a lot in between. That we occasionally see the skull in the mirror should serve to prod us forward, not to plunge us into despair. 
JS: I think of all of these dialogues as suicide notes we will have left behind: at once life- and death-sentences, as I said earlier. But the glad tidings are, I suppose, that the Hemlock Society would not have me for a member. And certainly you are not one of them. I don't love my fate or the Yorick beneath my thinning hair, but it's clear that my mortality has chiseled out whatever existential shapeliness I have. And yet I cannot celebrate that fact. I can look upon it with a kind of rueful wistfulness and-I have to say-a certain embarrassment. Better never to have been born at all than face the diurnal round of rocks, stones, trees, students, blue books, exiting wives and the incandescent consciousness that all of this strutting-and-fretting signifies nothing. I have been hanging myself, slowly, since I was ten years old. And it has given me no erection of any kind. So what's the point?

RB: The point to life is whatever you make of it. And if you make nothing of it, then there is no point. My plan: a happy life followed by a quick death. The rest is white noise.

JS: It's not that I make nothing of life. It's that death will make nothing of me. And yet I don't get up at four in the morning just to be-and live-like everyone else. You are the more, I the less cheerful existentialist. You are the Prince of your ambitions. I am Death's pawn. But-as a Persian proverb reminds us-at the end of the game all the pieces go into the same box.

RB: What can I say but ... "Checkmate!” 